Бортнік Наталія

бакалавр психології, студентка VI курсу психолого-природничого факультету, Рівненський державний гуманітарний університет DOI https://doi.org/10.35619/praprv.v1i15.180

\title{
ВПЛИВ СТИЛЮ СІМЕЙНОГО ВИХОВАННЯ НА САМООЦІНКУ МОЛОДШИХ ШКОЛЯРІВ
}

\begin{abstract}
Анотація. Стаття вивчає вплив стилю сімейного виховання на формування самооиінки молодшого школяра. Особливу увагу приділено розгляду взаємозв'язку стилю сімейного виховання (та особистісних якостей батьків), та процесу формування особистості дитини, рівня його пристосованості, здатність до адаптації до умов соиіального середовищя.

Автор розкриває особливості й прояви стилів сімейного виховання, проаналізовано наступні фактори, щуо впливають на вибір поведінкових стратегій батьків: насамперед тип темпераменту та традииії, в яких виховувались самі батьки.
\end{abstract}

Проаналізовано існуючі стилі батьківського виховання: авторитетний: характеризується теплим емоційним прийняттям дитини і високим рівнем контролю з боку дорослих; авторитарний: характеризується високим рівнем вимогливості до дитини, покаранням невдач, жорстоким контролем, втручанням в особистий простір дитини, пригніченням індивідуальності дитини силою; індиферентний: характеризуються відсутністю теплоти в ставленні до дитини, зневажливим відношенням, ігноруванням його емочійних потреб; ліберальний: передбачає тактику невтручання, основу якої, складають байдужість $і$ незацікавленість проблемами дитини. Розкрито особливості формування самооцінки в молодших школярів, насамперед, під впливом результатів навчальної діяльності, та прийняття референтних осіб. Визначено, на залежність вибору стилю сімейного виховання на формування самооиінки молодших школярів та особливостей поведінкових проявів індивіда.

Зроблено висновки в контексті теми впливу стратегій сімейного виховання, щзо авторитетний стиль, провокуе високу самооцінку, самоприйняття та самоконтроль індивіда; авторитарний стиль - низький рівень домагань та занижену самооиінку; індиферентний стиль - можливий розвиток у дітей емоційної відчуженості, тривожності, замкнутості і недовіри до оточуючих або висока сила волі, прояви творчого потенціалу, активність, просоиіальність (як високий рівень компенсаторності особистості); ліберальний - високий рівень (неадекватність) самооиінки особистості. Подальший розгляд иієї проблеми вбачаємо в більш розгорнутому вивченні основних стилів сімейного виховання, та їх впливу на формування індивідуальних особистісних аспектів в цілому.

Ключові слова: стиль сімейного виховання, поведінкові стратегї, самоочінка, саморозуміння, рівень домагань.

Постановка проблеми. Сьогодні однією із найактуальніших проблем у психології сімейних відносин $є$ питання впливу стилю сімейного виховання на формування особистості дитини. Вивчення даного явища актуалізовано в роботах багатьох вчених, зокрема, Ілліних розглядав взаємозв'язок між стилем сімейного виховання та розвитком особистісних якостей дитини. Коритченкова вивчала механізми прояву дитячої агресивності та тривожності та їх взаємозв'язок зі стилем сімейного виховання. Амеліна, Ковальова, Колеснікова, Кузьмишина, Пермякова, Хохлов здійснили аналіз впливу стилю сімейного виховання на соціальну адаптацію дітей. Лічко, Захаров, Ейдеміллер розглядали взаємозв'язок стилю сімейного виховання (та особистісних якостей батьків), та процесу формування особистості дитини, рівня його пристосованості, здатність до адаптації до умов соціального середовища. 
Однак проблема впливу сімейного стилю виховання на формування особистості дитини не втрачає своєї актуальності, зважаючи на іiі багатогранність та складність при вивченні структури системи впливів на становлення індивіда. Одним 3 таких напрямків $\epsilon$ питання впливу даних стилів на самооцінку молодших школярів, оскільки в останні роки ідея про визначальну роль активності особистості у власному розвитку стала в педагогіці загальновизнаною. В даний час системоутворюючим ядром індивідуальності $є$ самооцінка особистості, яка багато в чому визначає життєві позиції індивіда, рівень його домагань, систему оцінок.

Самооцінка розуміється як необхідний елемент розвитку самосвідомості, як застосування оцінок до власного «Я». У зв'язку з цим особистісно-орієнтована парадигма актуалізує завдання побудови нових освітніх технологій, здатних ініціювати процес самооцінки, саморозвитку та самоствердження особистості, націлених на сприяння розвитку можливостей індивіда у всіх його проявах, на зміну мотиваційних конструктів особистості, та безпосередньо стилю сімейного виховання на розвиток у дитини таких якостей, як впевненість, відсутність страху помилитися, позитивна оцінка свої можливості. Молодший шкільний вік $є$ періодом інтенсивного формування самооцінки, що обумовлено включенням дитини в нову суспільно значиму і оцінювану діяльність. До завершення молодшого шкільного періоду самооцінка дитини стає автономною і в меншій мірі залежною від думки оточуючих. $€$ всі підстави вважати, що вивчення даних психологічних аспектів $€$ важливим, для ефективного виконання психолого-педагогічних функцій освітніх закладів, збереження психічного здоров'я дітей та вдосконалення психологічного культури суспільства в цілому.

Враховуючи важливість вивчення впливу стилю сімейного виховання на самооцінку молодших школярів для сучасної психологічної науки та зростаючий інтерес дослідників до цієї теми, було здійснено теоретичний аналіз вищезазначеної теми, для можливості розширення спектру психологічних знань та впровадження їх в систему методологічного супроводу навчального середовища.

Аналіз останніх досліджень 3 проблеми. Стилі виховання дітей - це група поглядів та поведінки, що стосуються виховання особистості (Darling N., Steinberg L., 1993 ). Дж. Бауермейстер (1995) зазначає два основних стилі: чутливий, який базується на теплі, взаємопідтримці та належній самостійності, зберігаючи тверді та послідовні обмеження щодо дітей; та примусовий - заснований на фізичному покаранні, відсутності послідовності та неефективному встановленні обмежень.

Деякі аспекти стилів сімейного виховання, такі як відповідна автономія та теплота, можуть слугувати опорою, для дослідження індивідом свого мікро та макто-простору (SohLeong, Lim, 2003; Garn, 2010 ; Masud, 2015). Відсутність узгодженості або неефективні межі, формують низький рівень особистісних домагань індивіда (Osorio, Gonzalez-Cámara, 2016; Checa, Rueda, 2017 ).

Мета статті. Здійснити теоретичний аналіз впливу стилів сімейного виховання на самооцінку молодших школярів, висвітлити та систематизувати основні положення наукових публікацій з вказаної теми.

Відповідно до зазначеної мети, було висунуто такі завдання: проаналізувати види й прояви стилів сімейного виховання; розкрити особливості формування самооцінки в молодших школярів; висвітлити особливості поведінкових проявів особистості в залежності від стилю сімейного виховання.

Виклад основного матеріалу дослідження. Стилі сімейного виховання формуються під впливом об'єктивних та суб'єктивних факторів. На вибір стилю сімейного виховання батьками впливає насамперед тип темпераменту, традиції, в яких виховувались самі батьки, науково-педагогічна література, до якої вони звертаються при виборі стилю спілкування 3 дитиною (Pellerone, 2017, p. 69 - 77). Шнайдер вказує, що стиль сімейного виховання, розуміється як сукупність батьківських стереотипів, що впливають на дитину у всіх сферах іiі життєдіяльності. Батьківський стиль представляє собою психологічний конструкт, який включає стандартні стратегії, які батьки використовують при взаємодії з дітьми (Чека 2011, c. 1018 - 1032). 
Аналіз наукової літератури, вказує на те, що стилі виховання - це відображення того, як батьки реагують на своїх дітей і висувають вимоги до них. Практики виховання $\epsilon$ специфічною поведінкою, тоді як стилі виховання представляють більш широкі моделі батьківських практик. (Бреслау 2011, с. 433 - 437) Існують різні теорії та думки щодо найкращих способів виховання дітей, а також різного рівня часу та зусиль, які батьки готові вкласти. Булл (2001) вказує: цінності подружжя, як життєві, так і сімейні, набуті в процесі створення та функціонування, відіграють певну роль у сімейних відносинах, особливостях взаємодії батьків та дитини та формуванні типу сімейного життя.

Ранні дослідження батьківства та розвитку дитини Гонсалеса, Міллсапа (2009) показали, що батьки, які забезпечують своїх дітей належним вихованням, незалежністю та твердим контролем, мають можливість виховати дитину 3: високим рівнем компетентності, соціальною кваліфікованістю та досвідченістю. Наявність форм любові та виховання дітей 3 турботою та прихильністю сприяє позитивному фізичному та розумовому прогресу у дітей. Додаткові навички розвитку $\epsilon$ результатом позитивних батьківських стилів, зокрема: підтримка тісних стосунків з іншими, самозабезпечення та незалежність. Баумрінд у своєму дослідженні виявила чотири основні елементи, які можуть допомогти сформувати успішне батьківство: чуйність проти невідповідності та вимогливість проти невибагливості (Pellerone 2017, p.69-77).

В ході своїх досліджень Баумрінд виділила три початкові стилі виховання: авторитетне, авторитарне та дозвільне батьківство. Маккобі, Мартін розширили три оригінальні стилі виховання Баумрінд, розмістивши стилі виховання у дві різні категорії: вимогливість та невибагливість (Манніно 2017, с. 318 - 333). За допомогою цих відмінностей було визначено чотири нові стилі батьківства:

1. Авторитетний або демократичний стиль виховання: батьки в займають лідируючі позиції, будучи авторитетом для дитини. Цей стиль характеризується теплим емоційним прийняттям дитини і високим рівнем контролю з боку дорослих. При такому стилі спілкування батьки орієнтовані на особистість дитини, її активні ролі в родині (Пелергіна, 2003, с. 651 - 665). Дитина виховується як самостійна, самобутня особистість, в такій сім'ї практично відсутні фізичні покарання і словесна агресія, батьки намагаються використовувати логіку в спілкуванні з дітьми, прагнуть домовитися.

2. Авторитарний стиль виховання: характеризується високим рівнем вимогливості до дитини, покаранням невдач, жорстоким контролем, втручанням в особистий простір дитини, пригніченням індивідуальності дитини силою. Особа яка, схильна до вибору авторитарного стилю виховання, має тенденції до ігнорування думки дитини та iï прав на самопрояви. Авторитарний стиль виховання має на увазі рішення конфліктів методом «батога і пряника», заборонами і погрозами, а не знаходженням компромісного рішення (Pellerone 2017, p. $69-77$ ).

3. Індиферентний стиль виховання: характеризуються відсутністю теплоти в ставленні до дитини, зневажливим відношенням, ігноруванням її емоційних потреб (Pellerone 2017, p. $69-77)$.

4. Ліберальний стиль виховання: передбачає тактику невтручання, основу якої, складають байдужість і незацікавленість проблемами дитини. Спільними особливостями ліберального та авторитарного стилів спілкування, є дистантність відносин, відсутність довіри, відособленість, відчуженість, демонстративне підкреслення свого домінуючого положення батьками (Pellerone 2017, p. 69 - 77).

Зважаючи на вище зазначені теоретичні відомості, в контексті даної теми варто вказати, на те що стиль сімейного виховання, безпосередньо може впливати на рівень самооцінки, яка визначає активність особистості, іiі прагнення до самоосвіти, іiі участь у житті колективу. Самооцінка формується, насамперед, під впливом результатів навчальної діяльності, та прийняття референтних осіб, особливо в молодших школярів. Прийнято розрізняти адекватну (або реальну) та неадекватну (завищену або занижену) самооцінку. Ці визначення проявляються у порівнянні з реальними можливостями молодшого школяра. 
Самооцінка не залишається стабільною, залежно від успіху в діяльності, вікових особливостей вона має тенденцію змінюватися (Pellerone 2015, p. 239 - 249).

Виготський вказує на те, що саме у віці семи років починає формуватися самооцінка - узагальнене, тобто стабільне, неситуативне i, водночас, диференційоване ставлення дитини до себе. Самооцінка опосередковує ставлення дитини до себе, інтегрує досвід іiі діяльності, спілкування з іншими. Це найважливіший особистий екземпляр, який дозволяє контролювати власну діяльність 3 точки зору нормативних критеріїв, будувати свою цілісну поведінку відповідно до соціальних норм (Думка 2009, с. 588 - 599). Гервасі (2017) в своїх дослідженнях вказує на те, що у навчальній діяльності молодший школяр потребує вміння ставити цілі та контролювати свою поведінку, управляти собою. Для здійснення даних процесів індивіду необхідні знання про себе - самооцінка. Процес формування самоконтролю залежить від рівня розвитку самооцінки. Pinquart (2016) дослідив, що молодші школярі можуть здійснювати самоконтроль лише під керівництвом дорослого та за участю однолітків. Я-концепція є основою самооцінки молодших школярів. Самосвідомість дитини здійснюється у навчальній діяльності.

Аналізуючи вище зазначені результати теоретичних досліджень, можна вказувати на залежність вибору стилю сімейного виховання на формування самооцінки молодших школярів, та на такі наслідки кожного з стилів. Внаслідок авторитетного стилю виховання відбувається найбільш гармонійне різнобічний розвиток особистості дитини. Для індивідів, вихованих в подібних сім'ях, характерні (Chandler 2009, p. 337 - 346):

- висока самооцінка, самоприйняття, самоконтроль;

- уміння самостійно приймати рішення і відповідати за свої вчинки;

- ініціативність та цілеспрямованість;

- уміння будувати близькі і доброзичливі відносини з оточуючими;

- здатність домовлятися, знаходити компромісні рішення;

- наявність власної думки і здатність вважатися з думкою оточуючих.

Характерним рисами особистості дитини, вихованого в авторитарному стилі, можуть бути наступні варіанти (Ocopio 2016, p. $414-420$ ):

- втрата почуття власної гідності;

- низький рівень домагань та занижена самооцінка;

- втрата здатності приймати рішення, відповідати за вибір;

- вирішення питань тільки силою;

- груба, цинічна, деспотична і хамську поведінка по відношенню до оточуючих;

- підвищена агресивність і конфліктність.

Наслідками індеферентного стилю сімейного виховання будуть (Гарн 2010, р. 263 272):

- можливий розвиток у дітей емоційної відчуженості, тривожності, замкнутості і недовіри до оточуючих;

- небезпека залучення дітей в асоціальні групи, оскільки батьки не здатні контролювати їх вчинки;

- безвідповідальність і невпевненість індивіда;

- висока сила волі, прояви творчого потенціалу, активність, просоціальність (як високий рівень компенсаторності особистості).

Для індивідів, вихованих в сім'ях 3 ліберальних стилем вихованні, характерні наступні індивідуальні особливості та поведінкові прояви (Гарн 2010, р. 263 - 272):

- незалежність індивіда;

- вміння проявляти себе, легкість самовираження індивіда;

- схильність до асоціальної поведінки;

- високий рівень (неадекватність) самооцінки; 
- нездатність до близькості й прихильності;

- низький рівень включеності в проблеми близьких.

Особи 3 адекватною самооцінкою активні, винахідливі, веселі, із зацікавленням i самостійно шукають у своїй роботі помилки, вибирають завдання, що відповідають їхнім можливостям. Індивідів з високою адекватною самооцінкою відрізняє активність, прагнення досягти успіху в навчальній діяльності. Для них характерна максимальна самостійність. Вони впевнені, що власними зусиллями зможуть досягти успіху в освітній діяльності. Це базується на правильній самооцінці власних можливостей та здібностей (Карло 2018, с. 577 592). Неадекватна низька самооцінка серед молодших школярів яскраво проявляється в їх поведінці та рисах особистості. Діти вибирають легкі завдання. Здається, вони цінують свій успіх, бояться його втратити, і через це вони дещо бояться самої освітньої діяльності. Нормальному розвитку дітей із заниженою самооцінкою перешкоджає підвищена самокритичність та невпевненість у собі. Вони очікують лише невдачі. Ці діти дуже чутливі до схвалення, до всього, що підвищило б їх самооцінку (Бреслау 2011, с. 433 - 437).

Висновки і перспективи подальших розвідок. Теоретичний аналіз психологічних аспектів стилів сімейного виховання на самооцінку підлітка дозволив проаналізувати наступні їх особливості в системі наукового знання: дане явище формується під впливом об'єктивних та суб'єктивних факторів та залежить від типу темпераменту та традиції, в яких виховувались самі батьки.

Аналізуючи теоретичні відомості, які висвітлюють проблему вибору впливу стилю виховання, вказано, що даний феномен розуміється як сукупність батьківських стереотипів, що впливають на дитину у всіх сферах іiі життєдіяльності. Батьківський стиль представляє собою психологічний конструкт, який включає стандартні стратегії, які батьки використовують при взаємодії з дітьми.

На основі узагальнення стану розробленої проблеми вказано на такі три початкові стилі виховання: авторитетне, авторитарне та дозвільне батьківство за Баумрінд, та чотири нові стилі батьківства за Маккобі, Мартін, які сформувалися після введення категорій розширення: вимогливість та невибагливість:

5. Авторитетний або демократичний стиль виховання: характеризується теплим емоційним прийняттям дитини і високим рівнем контролю з боку дорослих;

6. Авторитарний стиль виховання: характеризується високим рівнем вимогливості до дитини, покаранням невдач, жорстоким контролем, втручанням в особистий простір дитини, пригніченням індивідуальності дитини силою;

7. Індиферентний стиль виховання: характеризуються відсутністю теплоти в ставленні до дитини, зневажливим відношенням, ігноруванням іiі емоційних потреб;

8. Ліберальний стиль виховання: передбачає тактику невтручання, основу якої, складають байдужість і незацікавленість проблемами дитини.

Виявлено, що стиль сімейного виховання, безпосередньо може впливати на рівень самооцінки, яка визначає активність особистості, іiі прагнення до самоосвіти, іiі участь у житті колективу. А також, що самооцінка формується, насамперед, під впливом результатів навчальної діяльності, та прийняття референтних осіб, особливо в молодших школярів.

Висвітлено систему наслідків вибору, кожного 3 існуючих стилів виховання, та, безпосередньо їх вплив на формування самооцінки індивіда:

авторитетний стиль: висока самооцінка, самоприйняття, самоконтроль;

авторитарний стиль: низький рівень домагань та занижена самооцінка;

індиферентний стиль: можливий розвиток у дітей емоційної відчуженості, тривожності, замкнутості і недовіри до оточуючих або висока сила волі, прояви творчого потенціалу, активність, просоціальність (як високий рівень компенсаторності особистості);

- ліберальний стиль: високий рівень (неадекватність) самооцінки.

Подальший розгляд цієї проблеми вбачаємо в більш розгорнутому вивченні основних стилів сімейного виховання, та їх впливу на формування індивідуальних особистісних аспектів в цілому. 


\section{СПИСОК ПОСИЛАНЬ}

Бреслау, Н., Бреслау, Дж., \& Міллер, С. (2011). Проблеми поведінки у віці 6 і 11 років та навчальні досягнення в середній школі: моделювання поздовжньої прихованої змінної. Psychiatry Res., 185, 433-437.

Булл, Р., \& Скеріф, Г. (2001). Виконавче функціонування як предиктор дитячих математичних здібностей: гальмування, перемикання та робоча пам'ять. Dev. Neuropsychol, 19, 273-293.

Гарн, А. С., Меттьюз, М. С., \& Джолли, Дж. Л. (2010). Вплив батьків на академічну мотивацію обдарованих учнів: перспектива теорії самовизначення. Gift. Child Q, 54, 263-272.

Гервасі, А. М., Ла-Марка, Л., \& Манніно, Г., (2017). Дезадаптивні риси особистості та симптоми залежності від Інтернету серед молодих людей: дослідження, засноване на альтернативній моделі DSM-5 для розладів особистості. Clin. Neuropsychiatry, 14, 2028.

Карло, Г., Стрейт, К., \& Найт, Г. П. (2018). Поздовжні відносини між стилями батьківства, просоціальною поведінкою та результатами навчання у підлітків Мексики в США. Child Dev., 89, 577-592.

Манніно, Г., \& Каронія, В. (2017). Час, добробут і щастя: попереднє дослідне дослідження. Світове майбутне, 73, 318-333.

Опініон, Л. Е., Гонсалес, Н. А., \& Міллсап, Р. Е. (2009). Академічний успіх хлопчиків і дівчаток-підлітків мексиканського походження: роль батьків та батьків у вихованні та культурній орієнтації. Статеві ролі, 60, 588-599.

Ocopio, А., \& Гонсалес-Камара, М. (2016). Тестування передбачуваної переваги поблажливого стилю батьківства серед іспанських підлітків. Психотема, 28, 414-420.

Пелегріна, С., Крус Гарсія-Лінарес, М., \& Казанова, П. Ф. (2003). Уявлення підлітків та їх батьків про батьківські особливості. Хто може краще передбачити академічну компетентність підлітка? Дж. Адолеск, 26, 651-665.

Чека, П., \& Руеда, М. (2011). Поведінкові та мозкові заходи виконавчої уваги та шкільної компетентності у пізньому дитинстві. Front. Psychol., 36, 1018-1032.

Chandler, M., Heffer, R., \& Turner, E. (2009). The Influence of Parenting Styles, Achievement Motivation, and Self-Efficacy on Academic Performance in College Students". Journal. College Student Development, 50, 337-346.

Pellerone, M., Passanisi, A., \& Bellomo, M. F. P. (2015). Identity development, intelligence structure, and interests: a cross-sectional study in a group of Italian adolescents during the decision-making process. J. Psychol. Res. Behav. Manag., 8, 239-249.

Pellerone, M., Ramaci, T., Parrello, S., Guariglia, P., \& Giaimo, F. (2017). Psychometric properties and validation of the Italian version of the family assessment measure third edition - short version - in a nonclinical sample. Psychol. Res. Behav. Manag., 10, 69-77.

Pinquart, M. (2016). Associations of parenting styles and dimensions with academic achievement in children and adolescents: a meta-analysis. Educ. Psychol. Rev., 28, 475-493.

\section{REFERENCES}

Breslau, N., Breslau, J., \& Miller, E. (2011). Problemy povedinky u vitsi 6 i 11 rokiv ta navchal'ni dosyahnennya $\mathrm{v}$ seredniy shkoli: modelyuvannya pozdovzhn'oyi prykhovanoyi zminnoyi [Behavioral problems at the age of 6 and 11 years and educational achievements in high school: modeling of the longitudinal hidden variable]. Psychiatry Res., 185, 433-437. [in Ukrainian].

Bull, R., \& Skerif, G. (2001). Vykonavche funktsionuvannya yak predyktor dytyachykh matematychnykh zdibnostey: hal'muvannya, peremykannya ta robocha pam"yat'. 
[Executive functioning as a predictor of children's mathematical abilities: executive functioning as a predictor of children's mathematical abilities: braking, switching and working memory]. Dev. Neuropsychol, 19, 273-293. [in Ukrainian].

Garn, A. S., Matthews, M. S., \& Jolly, J. L. (2010). Vplyv bat'kiv na akademichnu motyvatsiyu obdarovanykh uchniv: perspektyva teoriyi samovyznachennya

[The influence of parents on the academic motivation of gifted students: the perspective of the theory of self-determination]. Gift. Child Q., 54, 263-272. [in Ukrainian].

Gervasi, A. M., La Marca, L., \& Mannino, G., (2017). Dezadaptyvni rysy osobystosti ta symptomy zalezhnosti vid Internetu sered molodykh lyudey: doslidzhennya, zasnovane na al'ternatyvniy modeli DSM-5 dlya rozladiv osobystosti [Deadaptive personality traits and symptoms of Internet addiction among young people: a study based on an alternative model of DSM-5 for personality disorders]. Clin. Neuropsychiatry, 14, 20-28. [in Ukrainian].

Carlo, G., Straight, K., \& Knight, G. P. (2018). Pozdovzhni vidnosyny mizh stylyamy bat'kivstva, prosotsial'noyu povedinkoyu ta rezul'tatamy navchannya u pidlitkiv Meksyky v SSHA [Longitudinal relationships between parenting styles, prosocial behavior, and learning outcomes in Mexican adolescents in the United States]. Child Dev., 89, 577-592. [in Ukrainian].

Mannino, G., \& Coronia, W. (2017). Chas, dobrobut i shchastya: poperednye doslidne doslidzhennya [Time, well-being and happiness: a preliminary research study]. World future, 73, 318-333. [in Ukrainian].

Opinion, L. E., Gonzalez, N. A, \& Millsap, R. E. (2009). Akademichnyy uspikh khlopchykiv ta divchatok meksykans'koho pokhodzhennya: rol' bat'kiv u vykhovanni ta kul'turniy oriyentatsiyi [Academic success of boys and girls of Mexican descent: the role of parents in parenting and cultural orientation]. Gender roles, 60, 588-599. [in Ukrainian].

Osorio, A., \& Gonzalez-Camara, M. (2016). Testuvannya peredbachuvanoyi perevahy poblazhlyvoho stylyu bat'kivstva sered ispans'kykh pidlitkiv [Testing the expected benefits of indulgent parenting style among Spanish adolescents]. Psychothem, 28, 414-420. [in Ukrainian].

Pellegrina, S., Cruz Garcia-Linares, M., \& Casanova, P. F. (2003). Uyavlennya pidlitkiv ta yikh bat'kiv pro bat'kivs'ki osoblyvosti. Khto mozhe krashche peredbachyty akademichnu kompetentnist' pidlitka? [Representation of adolescents and their parents about parental characteristics. Who can better predict a teenager's academic competence?]. J. Adolesque, 26, 651-665. [in Ukrainian].

Cheka, P., \& Rueda, M. (2011). Povedinkovi ta mozkovi zakhody vykonavchoyi uvahy ta shkil'noyi kompetentnosti u pizn'omu dytynstvi [Behavioral and brain measures of executive attention and school competence in late childhood]. Front. Psychol., 36, 1018-1032.

Chandler, M., Heffer, R., \& Turner, E. (2009). The Influence of Parenting Styles, Achievement Motivation, and Self-Efficacy on Academic Performance in College Students"Journal. College Student Development, 50, 337-346. [in English].

Pellerone, M., Passanisi, A., \& Bellomo, M. F. P. (2015). Identity development, intelligence structure, and interests: a cross-sectional study in a group of Italian adolescents during the decision-making process. J. Psychol. Res. Behav. Manag., 8, 239-249. [in English].

Pellerone, M., Ramaci, T., Parrello, S., Guariglia, P., \& Giaimo, F. (2017). Psychometric properties and validation of the Italian version of the family assessment measure third edition - short version - in a nonclinical sample. Psychol. Res. Behav. Manag., 10, 69-77. [in English].

Pinquart, M. (2016). Associations of parenting styles and dimensions with academic achievement in children and adolescents: a meta-analysis. Educ. Psychol. Rev., 28, 475-493. [in English]. 
THE INFLUENCE OF FAMILY UPBRINGING STYLE ON THE SELF-ESTEEM OF JUNIOR SCHOOLCHILDREN

\author{
Bortnik Natalia \\ Bachelor of Psychology \\ VI year student of the Faculty of Psychology and Natural Sciences \\ Rivne State University of Humanities \\ DOI https://doi.org/10.35619/praprv.v1i15.180
}

\begin{abstract}
The article examines the influence of family upbringing style on the formation of selfesteem of junior schoolchildren. Particular attention is paid to the relationship between the style of family upbringing (and personal qualities of parents), and the process of forming the child's personality, the level of his adaptation, the ability to adapt to social conditions.

The author reveals the features and manifestations of family upbringing styles, analyzes the following factors influencing the choice of behavioral strategies of parents: first of all, the type of temperament and traditions in which the parents themselves were brought up.

The existing styles of parental upbringing are analyzed: authoritative: characterized by warm emotional acceptance of the child and a high level of control by adults; authoritarian: characterized by a high level of demanding of the child, the punishment of failures, cruel control, interference in the personal space of the child, the suppression of the child's personality by force; indifferent: characterized by a lack of warmth in relation to the child, contemptuous attitude, ignoring his emotional needs; liberal: involves tactics of non-interference, the basis of which is indifference and disinterest in the problems of the child.

The peculiarities of the formation of self-esteem in junior schoolchildren, first of all, under the influence of the results of educational activities, and the acceptance of reference persons are revealed.

The dependence of the choice of family upbringing style on the formation of self-esteem of junior schoolchildren and the peculiarities of the individual's behavioral manifestations is determined.

Conclusions are made in the context of the topic of the influence of family education strategies, that authoritative style provokes high self-esteem, self-acceptance and self-control of the individual; authoritarian style - low level of harassment and low self-esteem; indifferent style - the possible development of children's emotional alienation, anxiety, isolation and distrust of others or high willpower, manifestations of creative potential, activity, prosociality (as a high level of compensatory personality); liberal - a high level (inadequacy) of self-esteem. We see further consideration of this problem in a more detailed study of the main styles of family upbringing, and their impact on the formation of individual personality aspects in general.
\end{abstract}

Key words: style of family upbringing, behavioral strategies, self-esteem, self-understanding, level of claims. 